\title{
A new species and a neotypification in Australian Tribulus (Zygophyllaceae)
}

\author{
K.L. Wilson
}

\begin{abstract}
Wilson, K.L. (National Herbarium of New South Wales, Royal Botanic Gardens, Sydney, NSW, Australia 2000) 1992. A new species and a neotypification in Australian Tribulus (Zygophyllaceae). Telopea 5(1): 21-29. A new species, Tribulus eichlerianus, is described from Queensland, New South Wales, Northern Territory and South Australia. A neotype is chosen for T. occidentalis $\mathrm{R}$. Br. These two species and T. hystrix $\mathrm{R}$. Br. are the only Australian species with numerous spines on the fruits. Differences between these three species are discussed.
\end{abstract}

\section{Introduction}

Australia has about twelve species of Tribulus L. sens. strict. (that is, excluding Tribulopis $\mathrm{R}$. Br.). The most widespread species is $T$. terrestris, which, as currently recognised, may include both native and weedy introduced forms, even after $T$. micrococcus Domin and T. minutus Leich. ex Benth. are separated (Wilson in prep.). This paper deals only with the strictly native species that have many-spined fruits: T. hystrix R. Br., T. occidentalis $\mathrm{R}$. Br. and an unnamed species for which a name is needed in the forthcoming 'Flora of New South Wales' volume 3. The new species has been confused with T. occidentalis. The latter species does not occur in New South Wales but, to stabilise application of the name, a neotype is here chosen.

Tribulus eichlerianus K.L. Wilson, sp. nov.

Affinis T. occidentali sed fructibus dense villosis, spinis fructus brevioribus, pedicellis tempore florescentiae brevioribus, differt.

TYPE: NORTHERN TERrITORY: Central North: Sandover Highway, $5 \mathrm{~km}$ SW of Utopia turn-off, K.L. Wilson $4646 \&$ R. Barker, 17 April 1983; holo NSW; iso CANB, NT.

Prostrate, \pm villous, taprooted herb with long radiating branches to $1 \mathrm{~m}$ long. Leaves opposite, pinnate, with 6-9 pairs of leaflets; leaflets \pm oblong, acute to broad-acute, base often oblique, discolorous, sparsely villous adaxially, more densely villous abaxially, 7-15 mm long, 3-6 mm wide. Flowering pedicels 7-16 $\mathrm{mm}$ long, elongating to $20-35 \mathrm{~mm}$ long in fruit. Sepals acuminate, densely villous abaxially, 4-7 mm long. Petals bright yellow, obovate, glabrous, 5-11 mm long, from slightly longer than sepals to twice as long as sepals. Anthers 10, 0.6-0.8(-1.5) $\mathrm{mm}$ long. Stigma elongatedconical, 1.3-2.5 mm long, longer than style. Fruit breaking up into 5 broad, woody cocci, sometimes 1 or 2 poorly developed; body of fruit $7-13 \mathrm{~mm}$ long, $10-20 \mathrm{~mm}$ diam. (excluding the spreading spines), densely villous (hairs to $1 \mathrm{~mm}$ long, thicker terminal bristle on each spine c. $2.5 \mathrm{~mm}$ long), with numerous spines abaxially of various lengths on the one fruit; spines rigid, spreading at right angles to the coccus surface, $0.5-5 \mathrm{~mm}$ long (most spines on the one fruit less than $2 \mathrm{~mm}$ long, often only 2-6 spines exceeding that length), covered in spreading white hairs. Seeds $3-5$ per coccus. Figure 1. 


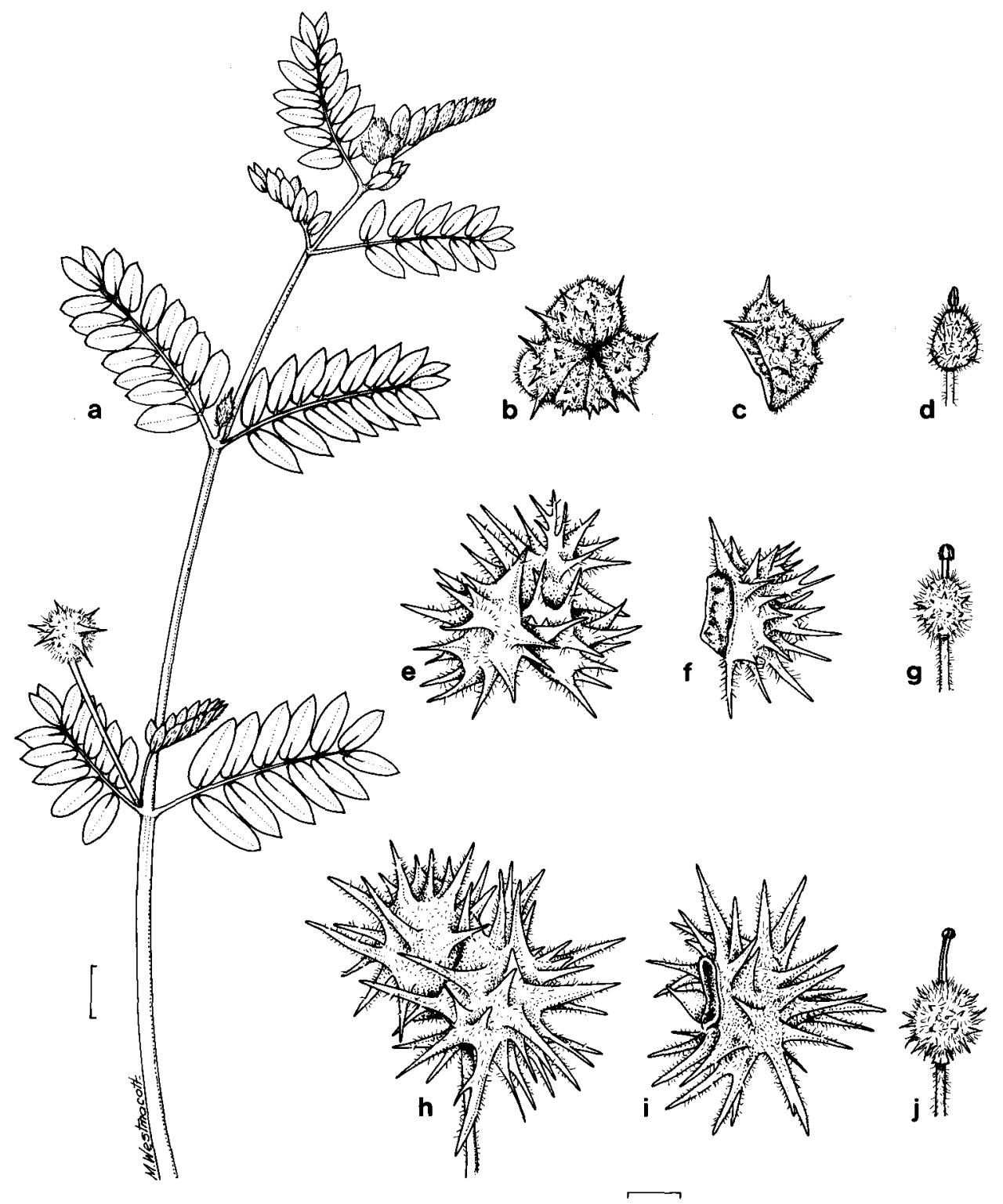

Figure 1. Tribulus eichlerianus: a, the apex of a branch (the indumentum of which has largely been omitted); $b$, plan view of fruit; $\mathbf{c}$, side view of one coccus; $d$, immature fruit with stigma and very short style. T. occidentalis: $\mathbf{e}$, plan view of fruit; $\mathbf{f}$, side view of one coccus; $\mathbf{g}$, immature fruit with stigma and style of similar lengths. $T$. hystrix: $\mathbf{h}$, three-quarter view of fruit with stalk attached; $i$, side view of one coccus; $j$, immature fruit with short stigma and very long style.

a, c from Perry 3286; b, d from Basedow NSW 145406; e-g from Ballingall 2561; h, i from Wilson 4601 ; j from Jacobs 5846 . a: scale bar $=10 \mathrm{~mm}$; b-j: scale bar $=5 \mathrm{~mm}$. 
Distribution AND Habitat: Found in arid and semi-arid Australia, from western Northern Territory to northern South Australia, western Queensland and New South Wales. Apparently usually in dry but non-saline habitats, often as a pioneer species (e.g. in dry creek-beds). The Dareton (south-western N.S.W.) record is perhaps an introduction in that irrigation area.

DeRIVATION OF EPITHET: Named after the late Dr Hansjoerg Eichler (1916-1992), who contributed notably to our understanding of the Australian flora, especially the family Zygophyllaceae, over many years. In addition to his own studies, he encouraged many others during his career in Adelaide and later in Canberra to contribute in their individual ways to systematic botany. Whimsically, Hansjoerg had suggested to me that I should explain the epithet as follows: 'The fruit of the species resembles the person it is named after - prickly, but not as prickly as some.'

Notes: In the classification of the genus by Hadidi (1978), this species falls within Tribulus sect. Tribulus (sect. Terrestris Hadidi), along with the type species $T$. terrestris, and T. occidentalis, T. hystrix and various other species with spiny cocci and deciduous sepals.

This species differs from $T$. terrestris, which may be found in the same areas, in having larger flowers with more conspicuous petals and a longer stigma and style. In addition, $T$. eichlerianus has bigger, more densely hairy fruits, with more rounded cocci and with spines that are more numerous and scattered all over the abaxial surface of the coccus, whereas $T$. terrestris usually has two long well-developed spines on the upper half of the abaxial surface of the coccus, spreading at right angles to the coccus, and two shorter spines near the base of the coccus, spreading downwards.

$T$. eichlerianus has mostly been confused with $T$. occidentalis or referred to as 'sp. aff. occidentalis'. However, it differs from T. occidentalis in various features (Table 1). Its fruits differ in being densely villous with shorter, untoothed spines, the majority of spines on each coccus being generally no more than $2 \mathrm{~mm}$ long but with a few spines markedly longer (spines mostly 3-8 mm long in $T$. occidentalis). Spines on immature fruits of T. eichlerianus (e.g. Martensz 2758) are more or less uniformly long, as in immature fruits of $T$. occidentalis and $T$. hystrix, but this changes with maturity in $T$. eichlerianus. The petals in T. eichlerianus are mostly shorter (usually 10-20 mm long in $T$. occidentalis) and the flowering pedicel is shorter $(15-20(-35) \mathrm{mm}$ long in $T$. occidentalis) although it elongates in fruit to about the same length as in T. occidentalis (to $35 \mathrm{~mm}$ long). In addition, $T$. eichlerianus has the stigma much longer than the style whereas in T. occidentalis the stigma is $1.0-2.0 \mathrm{~mm}$ long and the style $1.0-3.0 \mathrm{~mm}$, that is, the two parts are more similar in length in the latter species. Label information is limited, as is my field knowledge of the two species (I have not seen T. occidentalis in the field), so I cannot say whether there is any habitat difference between these species. Distribution and typification of $T$. occidentalis, a mainly west-coast species, are discussed below.

$T$. eichlerianus differs from T. hystrix, the only other previously known Australian species with numerous spines, in having densely villous fruits with shorter untoothed spines, much smaller flowers (petals 15-27 mm long in T. hystrix), and the stigma longer than the style (the reverse in T. hystrix). Distinguishing features of these two species and T. occidentalis are given in Table 1.

The only extra-Australian species with numerous spines on the fruit are $T$. rajasthanensis M.M. Bhandari \& V.S. Sharma from India, Afghanistan and Arabia and T. echinops Kers from Angola and Namibia. I have seen only one specimen of the former (collected near Jaisalmer, Rajasthan, no. 3416 [no collector], 1 Sep 1976; CANB) and none of the latter, but both protologues give full descriptions and are accompanied by good illustrations. 
Table 1. Distinguishing features of $T$. eichlerianus, $T$. occidentalis and $T$. hystrix

$T$. eichlerianus $\quad T$. occidentalis $T$. hystrix

\section{Leaves}

Pairs of leaflets

per leaf

$6-9$

$7-11$

$7-10$

\section{Pedicel}

Flowering length ( $\mathrm{mm}$ )

$7-16$

Fruiting length $(\mathrm{mm})$

$20-35$

$15-20(-35)$

$15-40(-60)$

$15-35$

$25-40(-60)$

\section{Flowers}

Sepal length $(\mathrm{mm})$

Petal length $(\mathrm{mm})$

Anther length $(\mathrm{mm})$

Stigma length $(\mathrm{mm})$

Style length $(\mathrm{mm})$

Fruit

Diameter, incl.

spines $(\mathrm{mm})$

Indumentum

Number of cocci

well-developed

Coccus length,

excl. spines (mm)

Spines

$$
\text { 4-7 }
$$

5-11

$0.5-0.8(-1.5)$

$1.3-2.5$

$0.5-1.0$

10-20

dense; hairs

c. $1 \mathrm{~mm}$ long

\section{3-5}

7-13

numerous, some long, most short

not toothed

0.5-5 mm long sparse; hairs
11-13

15-27

(1.2-)1.6-2.3

$0.5-2.5$

4.0-6.0 sparse; hairs c. $0.5 \mathrm{~mm}$ long 2-3

$10-20$

numerous, long
15-25

c. $0.5 \mathrm{~mm}$ long

2-4

10-14

numerous, long

often toothed

(1-)3-8 mm long

often toothed 4-15 mm long 
T. rajasthanensis (Bhandari \& Sharma 1977) differs from T. eichlerianus in having a fruit covered in shorter hairs and with only two long spines that are always in a central position on the coccus surface, in contrast to the usually more numerous long spines on the coccus in T. eichlerianus. T. rajasthanensis also differs in having usually shorter and thinner cocci $(6-7 \mathrm{~mm}$ long), a short stigma that is shorter than the style, and longer anthers (1.5-1.7 mm long).

T. echinops (Kers 1971) has numerous elongated spines (4-14 $\mathrm{mm}$ long) covering the fruit, which makes the species look (at least superficially) more like T. hystrix than T. eichlerianus. The spines do not, however, appear to be toothed as in T. hystrix. Petals, anthers and fruit are all larger, and the stigma is shorter, than in T. eichlerianus.

\section{SELECTED SPECIMENS SEEN:}

QueEnsLAND: Gregory North: Toko Gorge, Toko Range, Purdie 2271, 10 July 1982 (CANB); Sandringham Station, Morton, Feb 1980 (NSW 145403); Currawilla, c. 100 miles [160 km] W of Windorah, Everist 3901, 9 June 1949 (CANB ex BRI). Gregory South: 38 miles [61 km] W of Windorah, Boyland 154, 18 Sep 1966 (NSW ex BRI).

New South WaLes: North Far Western Plains: Tibooburra, Morris 803, 30 Sep 1921 (NSW); Salisbury Downs Station, Martensz 2758, 11 Mar 1964 (CANB); c. $30 \mathrm{~km}$ NW of Milparinka on Hawkers Gate road, Jacobs 3501, 11 May 1979 (NSW, AD); Yandama, Milparinka, Collier, Mar 1910 (NSW 145396); Mt Browne, Corbett, May 1898 (NSW 145398); Callandary Station, Libke 1500, Apr 1967 (NSW); Broken Hill, Bennetts, - (NSW 145399). South Far Western Plains: Dareton, Parsons, 5 Mar 1980 (NSW 245400).

NoRTHeRn Territory: Central North: 27 miles [43 km] NE of Barrow Creek township, Lazarides 5824, 24 Aug 1956 (CANB, NSW). Central South: Acacia Well Bore, 25 miles [40 km] NE of Undoolya Station, Perry 3286, 6 Mar 1953 (CANB); 1 mile [1.6 km] E of Alice Springs township, Perry 3225, 5 Mar 1953 (CANB); Palm Valley, Cycad Gorge, Eichler 22642, 26 Aug 1978 (CANB); Uluru National Park: Kata Tjuta (The Olgas), on the Docker River road, $45 \mathrm{~km}$ WNW of the Ranger Station, Lazarides \& Palmer 081, 14 May 1988 (CANB, NSW).

SOUTH AustraLIA: North-western: Granite Downs, near the homestead, Eichler 17944, 14 July 1964 (CANB, NSW). Lake Eyre: 12 km NW of Moomba, Wasson ANU 31025, 14 June 1981 (CANB ex ANU); Kingoonya - Mount Eba, Basedow, Apr-May 1917 (NSW 145406); Priscilla Creek, 30 km NW of Finniss Creek on Oodnadatta road, Wilson 4600 \& R. Barker, 10 Apr 1983 (NSW, AD, CANB). Flinders Ranges: Munyallina Creek, 'Wooltana' - 'Balcanoona' road, Jacobs 3616, 17 May 1979 (NSW); c. 5 km N of Witchitie Station, Copley 3766, 20 Mar 1972 (CANB ex AD).

\section{Tribulus occidentalis R. Br.}

Brown (1849: 69)

TYPE CITATION: 'Found on the west coast of Australia, or on some of its islands, in the voyage of the Beagle'

NeOtYPE (here designated): WeStern Australia: Carnarvon: on the outskirts of Onslow town, near the hospital, D.E. Symon 5420, 1 July 1967 (CANB 209684). Isoneo: AD (n.v.), B (n.v.), CANB 209685, K (n.v.), PERTH (n.v.).

Robert Brown briefly but clearly described this species in a note following his description of $T$. hystrix. Unfortunately, the specimen or specimens of $T$. occidentalis collected on the voyage of the survey vessel 'Beagle' in 1837-1843 and seen by Brown cannot now be found in BM.

Bentham (1863) put T. occidentalis in the synonymy of T. hystrix but made it clear that he had not seen adequate material of either species; indeed, that he had not been able 
to find any of the specimens seen by Brown. This was partly confirmed by Moore (1920), who agreed that the type of $T$. occidentalis could not be found in BM but pointed out that the type of T. hystrix was certainly still present there. Moore did not comment on Bentham's detailed statement in the preface to 'Flora of Australia' (1863: $9^{*}$ [sic]) about the difficulty, if not impossibility, of getting access in BM to specimens such as those of the 'Beagle' voyage, beyond suggesting that Bentham's infrequent visits to the Museum accounted for his not finding the relevant specimens.

Moore (1920) discussed the differences between T. occidentalis and T. hystrix, as he understood the species, pointing out that the former has shorter sepals and petals, smaller fruits, and shorter spines (that vary less amongst themselves on the one fruit) compared to the latter. His plate 11 illustrates the fruits of both species but not well. He suggested that the pedicels were shorter in T. occidentalis, but this is not always so at either the flowering or fruiting stage. One difference not mentioned by him is the relative and absolute lengths of stigma and style: $T$. occidentalis has the stigma 1.0-2.0 $\mathrm{mm}$ long, slightly shorter than or equalling the style, while $T$. hystrix has the stigma $0.5-3.0 \mathrm{~mm}$ long, and no more than half as long as the style (which can be to $6 \mathrm{~mm}$ long).

Here, the name T. occidentalis is applied, in agreement with Moore (1920), to a taxon with numerous long spines that matches the protologue in all significant features. This species is most common on the north-west coast of Australia, extending from Carnarvon north to Broome.

T. occidentalis and T. hystrix are the only two Australian species that have numerous long spines (3-15 mm long) on the cocci of the fruit, both described by Brown (1849). Tribulus hystrix was based on a collection (BM!) made by Sturt in Central Australia, on sandhills at about the latitude of the current Queensland - South Australian border (west or south-west of Birdsville). Brown's brief description of this species was followed by the even briefer note describing $T$. occidentalis.

He distinguished T. occidentalis from T. hystrix on the basis of being silky-woolly, as opposed to woolly in T. hystrix [presumably this refers to the leaflets, stems and new shoots]; having about 8 pairs of leaflets per leaf (8-10 in T. hystrix); and having all the spines on the cocci equal in length and conical-subulate (spines unequal in length and subulate in T. hystrix).

Two of the features listed by Brown are not distinctive. Leaflet number varies considerably within any species of Tribulus (7-10 pairs of leaflets in T. hystrix, 7-11 in $T$. occidentalis). Indumentum also varies within a species, being affected by stage of growth and probably also by habitat conditions.

The only really distinctive characteristic mentioned by Brown is the form of the spines on the fruit (Figure 1, Table 1). Spines are numerous, long and toothed in both species, a condition found in no other Australian species. In T. occidentalis the spines are somewhat thicker and shorter than in T. hystrix. Brown refers to them all being of equal length in $T$. occidentalis but this is only superficially so in both species. While the overall appearance is of subequal spines in the specimens here referred to $T$. occidentalis, the spines actually vary from $1 \mathrm{~mm}$ to $8 \mathrm{~mm}$ long on a specimen. In T. hystrix, spines often range in length from $4 \mathrm{~mm}$ to $15 \mathrm{~mm}$ on any one fruit.

We do not know on which portion of the north-west coast of Australia visited by the 'Beagle' this species was collected because Stokes (1846) mentioned plants only very generally except in a very few cases. However, he did mention landing on various occasions in 1840-41 on islands and the mainland between Barrow Island and Red Hill (which is in the southern half of Eighty Mile Beach) - a stretch of coast that falls within the main distribution of the taxon here called $T$. occidentalis. 
Both species are found in the Pilbara region but $T$. occidentalis is much more common, especially near the coast. Three specimens from farther inland in Western Australia and south-western Northern Territory (George 15640, Latz 2127 \& 2420) probably also belong to $T$. occidentalis although they are more slender. It is not clear whether this patchy distribution is real or is an artifact of inadequate collecting in arid areas.

T. hystrix has only been collected a few times in the Pilbara; its main distribution is in and around the Simpson Desert, with only scattered collections farther west. Near the Northern Territory - Western Australian border, a few puzzling collections have been made: Fryxell et al. 4505, Gittins 2452 and Hunt 76/38. These have big flowers with long styles as in T. hystrix, but the fruits are somewhat smaller and only have short spines. They may be a short-spined form of T. hystrix, but further study needs to be made to discount other possibilities such as hybridisation or new taxa.

Other species found near the north-west coast of Australia include T. terrestris and possibly $T$. zeyheri Sond. but neither of these has numerous long spines and both differ in other features.

I conclude that it is possible to identify the taxon named T. occidentalis by Robert Brown, even in the absence of its type specimen. The type of T. hystrix, the other Australian species with numerous spines on the fruit, is extant, and has been compared with other specimens of the two species. All available data are in agreement with Moore's (1920) and my assessments of the application of the name T. occidentalis. Since the original specimen(s) mentioned by Brown still cannot be found, a neotype needs to be chosen for T. occidentalis.

Moore (1920) listed several other old specimens held at BM: North Goulburn Island, A. Cunningham; N.W. Coast, A. Cunningham 133 of 1818 voyage; N.W. Coast, De Bouley. I have seen only a photographic slide of the first two specimens, which are mounted on the same sheet. The North Goulburn Island specimen has buds and immature fruits apparently with numerous spines. I cannot be sure of the identity of this Northern Territory specimen. The locality is well outside the known range of $T$. occidentalis but there is, of course, the possibility of an incorrect locality. The other two specimens seem to be $T$. occidentalis. Moore also stated that there were other specimens (not listed by him) of this species at $\mathrm{K}$ that had been (wrongly) annotated by Bentham as $T$. hystrix. I have seen three specimens in $\mathrm{K}$ to which this comment apparently refers. Firstly, there is Ridley's Expedition ('Nicol Bay and De Grey River', sent December 1863 to Kew), which has been determined as T. hystrix? by Bentham and re-determined as $T$. occidentalis by Moore. It is a fruiting specimen of what is here called $T$. occidentalis. Secondly, A. Cunningham 133, First Voyage [of the 'Mermaid'] (presented by R. Heward 1862) has a flower with petals c. $11 \mathrm{~mm}$ long. Thirdly, and mounted on the same sheet as the second specimen, there is A. Cunningham ('N.W. Coast; T. echinatus v. cassioides'), which includes a flowering sprig (petals c. $12 \mathrm{~mm}$ long) and a piece with immature fruits with numerous spines. Both the specimens on this sheet have been annotated as T. hystrix? by Bentham, with no annotation by Moore. Both are $T$. occidentalis.

These old specimens of $T$. occidentalis are either not in very good condition or lack good collecting information, and so a recent specimen, Symon 5420 (sheet CANB 209684), which shows the diagnostic features of the species, is clearly and fully labelled, and has duplicates, is here chosen as neotype. This includes part of the base of a plant as well as various branches bearing flowers and fruit. There is also a less complete isoneotype, sheet CANB 209685, which consists of a fruiting branch taken from the lower right of sheet CANB 209684. 


\section{SELECTED SPECIMENS SEEN: Tribulus occidentalis}

Western Australia: Dampier: Broome, Mjoeberg 152, July 1911 (NSW), Symon 5344, 26 June 1967 (CANB ex AD), Kenneally 9389, 10 Aug 1985 (CANB ex PERTH). Fortescue: Nicol Bay and De Grey River, NW Australia, Ridley's Expedition, sent Dec 1863 (K); Shaw River crossing by Great Northern Highway to Port Hedland, c. $98 \mathrm{~km}$ by road NW of Marble Bar, Jackson 3018, 25 Aug 1977 (CANB ex AD); Port Hedland at wharf area, Ballingall 2552, 8 Aug 1989 (CANB); c. $35 \mathrm{~km}$ NNW of Goldsworthy, $11 \mathrm{~km}$ along Great Northern Highway - Shellborough track, Telford 6525, 6 Aug 1977 (CANB ex CBG); Dampier, at Dampier Clinic (Marine Biological Station), Eichler 23602, 28 Aug 1985 (CANB); NW Coastal Highway $15 \mathrm{~km}$ N of Fortescue River crossing, Ballingall 2561, 11 Aug 1989 (CANB); between the Ashburton and De Grey Rivers, Clement, purchased Aug 1900 (K). Carnarvon: Yannarie River at road crossing, Barradale Roadhouse, Ballingall 2567, 12 Aug 1989 (CANB); along North West Coastal Highway, $4.8 \mathrm{~km}$ SE of Minilya Roadhouse, Eichler 23625, 3 Sep 1985 (CANB); c. $14 \mathrm{~km}$ SE of Carnarvon along the North West Coastal Highway, Short 1574, 27 Aug 1982 (CANB).

\section{SPECIMENS SEEN: ?T. occidentalis (smaller flowers and fruits)}

NorTHERn Territory: Central North: Newhaven Station, Latz 2127, 19 Jan 1972 (NSW ex NT). Central South: S of Lake Neale, Latz 2420, 11 Apr 1972 (NT n.v., CANB, NSW)

WeSTERN Australia: Canning: Tobin Lake, Great Sandy Desert, George 15640, 6 May 1979 (NSW ex PERTH).

\section{SELECTED SPECIMENS SEEN: Tribulus hystrix}

QueEnSLand: Gregory North: Sandringham Station, Morton, Feb 1980 (NSW 144948). Gregory South: Poeppel Corner, Boyland 280, 24 Sep 1966 (CANB ex BRI, K); between Roseberth and Miranda, Filson 3375, 1 Oct 1960 (CANB).

NorTHERn Territory: Central South: Window Hill, Simpson Desert, Chippendale 1606, 8 Sep 1955 (CANB, NSW ex NT); Mayfield Swamp, Mitchell 97, 15 Aug 1974 (CANB ex NT).

South Australia: Lake Eyre: sandhills in about lat. $26^{\circ}$, Sturt (BM, holotype); Purni Bore, Mt Dare, Latz 4753, 3 Apr 1974 (CANB); Bloodwood Bore, Cordillo Station, U. Johnson 38, 16 June 1972 (NSW 128006, K); Priscilla Creek, $30 \mathrm{~km}$ NW of Finniss Creek on Oodnadatta road, K.L. Wilson 4601 \& R. Barker, 10 Apr 1983 (NSW, AD, CANB); Yandama Creek, 72 km SW of Hawker Gate, Jacobs 3554, 13 May 1979 (NSW, AD).

Western Australia: Fortescue: $3.3 \mathrm{~km}$ from the centre of Newman along the track to Coombanbunna Well, Mollemans 2449, 6 Mar 1987 (CANB). Carnarvon: $116 \mathrm{~km} \mathrm{~S}$ of Barradale, Carnarvon road, S. Jacobs 5846 \& P. Wilson, 8 June 1988 (NSW); $5 \mathrm{~km} \mathrm{~S}$ of Minilya River on NW Coastal Highway, Ballingall 2569, 13 Aug 1989 (CANB).

\section{SPECIMENS SEEN: ?T. hystrix (short-spined, smaller fruits)}

Northern Territory: Central North: on Tanami Track c. $472 \mathrm{~km} \mathrm{NW}$ of Alice Springs $(140 \mathrm{~km}$ SE of Rabbit Flat), Fryxell, Craven \& Stewart 4505, 25 May 1985 (CANB); alongside Tanami Creek, 306 miles [492 km] NE [sic] of Alice Springs, Hunt 76/38, 20 June 1976 (NSW).

Western Australia: Mueller: Bloodwood Bore, near Balgo, Gittins 2452, July 1972 (NSW). 


\section{Acknowledgments}

The late Hansjoerg Eichler was most helpful in discussions and in arranging access to material at CANB. Terry Macfarlane, Greg Leach, and Philip Short have all checked details of or photographed specimens for me during their terms as Australian Botanical Liaison Officer at Kew. The heads of the following herbaria are thanked for making specimens available to me either in situ or on loan: BM, CANB, K. Drawings were done by Marion Westmacott. Surrey Jacobs made useful comments on the manuscript.

\section{References}

Bentham, G. (1863) Flora Australiensis vol. 1.

Bhandari, M.M \& Sharma, V.S. (1977) A new Tribulus (Zygophyllaceae) from India. Bot. Notiser 129: 367-369.

Brown, R. (1849) Botanical appendix. Pp. 66-92 in C. Sturt, Narrative of an expedition into Central Australia vol. 2.

Hadidi, M.N. el (1978) An introduction to the classification of Tribulus L. Taeckholmia 9: 59-66.

Kers, L.E. (1971) Notes on the flora of Angola. Bot. Notiser 124: 16-24.

Moore, S. Le M. (1920) A contribution to the Flora of Australia. J. Linn. Soc. Bot. 45: 159-220, pl. $11,12$.

Stokes, J.L. (1846) Discoveries in Australia, 2 vols.

Manuscript received 26 November 1991

Manuscript accepted 13 February 1992 